\title{
Multi-criteria assessment tools for achieving balance between negotiating powers under distorted conditions of competition in construction sector's market
}

\author{
Kęstutis Peleckis ${ }^{1, *}$ \\ ${ }^{1}$ Department of Economics Engineering, Faculty of Business Management, Vilnius Gediminas \\ Technical University, Sauletekio al. 11, LT-10223 Vilnius, Lithuania
}

\begin{abstract}
Research background: this study identified which factors influence other factors and how they have a greater impact on the value of a business entity's $\mathrm{HHI}$ index. By knowing the key factors, they can be used to model possible mergers and their impact on the HHI index and possible changes in the market power balance.

Purpose of the article: to present the concept of business negotiation system, enabling to model and effectively manage the process of development and implementation of negotiation strategies, assessing the negotiating power of negotiating parties and selecting multi-criteria assessment tools to balance them in the conditions of distorted construction sector market competition.

Methods: multi-criteria assessment is used to assess the market power of business entities in business negotiations in order to select effective strategic solutions for construction sector's business negotiations.

Findings \& Value added: a developed algorithm for the development of construction sector's business negotiation strategy based on evaluations of bargaining power is presented.
\end{abstract}

Keywords: multi-criteria assessment; negotiation support; negotiation strategy; balance of negotiating powers; multiple decision-making; distorted competition; construction sector

JEL Classification: $C 78, C 3, D 4, F 14, L 74$

\footnotetext{
*Corresponding author: k.peleckis@vilniustech.lt
} 


\section{Introduction}

New challenges in international business negotiations raise the distorted competitive market situations - market concentration, cartels, monopolies and oligopolies. Therefore, the development and implementation of business negotiation strategies should be based on a scientific theoretical basis that meets these challenges. Developing and implementing a unique and effective strategy for construction sector's business negotiations the identification of essential features and causal links is important in order to make the most effective use of bargaining power.

Distorted market competition conditions pose new challenges in developing and implementing negotiation strategies of business entities in cooperation with foreign partners. Research shows that corporate negotiators, who are going to negotiations, usually do not have prepared business negotiation strategies, also they have no negotiation tactics systems. This is particularly important in the conditions of distorted market competition, which negatively affects the ability to balance the bargaining power of the negotiators. This confirms the need for research in this area.

\section{Overview of the use of concentration indices for concentration studies}

In the scientific literature, different authors present a number of theoretical ways to measure the degree of competition in the market (Albrecht, 2020; Yeh and Liao, 2020; Yung and Nguyen, 2020; Kadoič et al., 2017; Lee and Sung, 2021; Li et al., 2020; Marshall, 2021; Moul and Miller, 2021; Rahman et al., 2021). In this work, it is relevant in assessing the balance of bargaining power in the market. Many authors note that competition is usually measured on the basis of the following variables: market concentration, taxes, price marginal costs, and import penetration (Nickell, 1996; Blundell, 1999). Both approaches usually forms market as a representative firm and are trying to identify hypothetical parameters of change (Prayoonrattana et al. 2020, Gancevskaite, 2008). These coefficients we will discuss in the work and will identify which would be the best suited to assess the balance of bargaining power. Many different indices are used to measure concentration in financial markets, J.A. Bikker and K. Haaf (2002) distinguish the following key ones: Herfindahl-Hirschmann index (HHI), Lerner (L), k firm concentration ratio (CRk), Hall-Tideman index (HTI), Rosenbluth index (RI), detailed industrial concentration index (CCI), Hannah and Kay index (HKI), U index (U), Multiplication Hause index (Hm), Entropy measure (E) (Gancevskaite, 2008). Table 1 shows the limits and expressions of these indices.

Table 1. The limits and expressions of indices

\begin{tabular}{|c|c|c|}
\hline Ratio & Ration range & Ratio form \\
\hline Lerner Index & $0=\mathrm{L}=1$ & $L=\frac{P-M C}{P}$ \\
\hline The k concentration ratio & $0<C R_{k}=1$ & $C R_{k}=\sum_{i=1}^{k} S_{i}$ \\
\hline Gini Coefficent & $0=\mathrm{G}=1$ & $G=1-2 \int_{0}^{1} F(x) d_{x}$ \\
\hline The Herfindahl hirschman Index & $1 / n=H H I=1$ & $H H I=C_{H}=\sum_{i=1}^{k} S_{i}^{2}$ \\
\hline The Hall-Tideman Index & $0<H T I=1$ & $H T I=1 /\left(2 \sum_{i=1}^{n} t * S_{i}-1\right)$ \\
\hline
\end{tabular}




\begin{tabular}{|c|c|c|}
\hline The Rosenbluth Index & $0<R I=1$ & $R I=1 /(2 \mathrm{C})$ \\
\hline $\begin{array}{c}\text { The conprehensive industrial } \\
\text { concentration index }\end{array}$ & $0<C C I=1$ & $C C I=s_{1}+\sum_{i=2}^{n} S_{i}^{2} *\left(1+\left(1-S_{i}\right)\right)$ \\
\hline $\begin{array}{c}\text { The Hannah and Kay Index } \\
\text { The U Index }\end{array}$ & $1 / s_{1}=H K I=n$ & $H K I=\left(\sum_{i=1}^{n} S_{i}^{\alpha}\right)^{\frac{1}{1-\alpha}}, \alpha>0$ ir $\alpha \neq 1$, \\
\hline The Hause Index & $1 / n=U=8$ & $U=\left(\sum_{i=1}^{n} S_{i} *\left(S_{i} * n^{\frac{\alpha-1}{\alpha}}\right)\right)$ \\
\hline Entropy Measure & $0<H_{m}=1$ & $H_{m}\left(\alpha,\left\{S_{i}\right\}=\sum_{i=1}^{n} S_{i}^{2-\left(S_{i} *\left(S_{i} *\left(H H I-S_{i}^{2}\right)\right)^{\alpha}\right.}\right.$ \\
\hline Panzar-Rosse H index & $0=E=\log n$ & $E=-\sum_{i=1}^{n} S_{i}-\log _{2} S_{i}$ \\
\hline
\end{tabular}

Sources: Bikker and Haaf (2002); Gancevskaitè (2008); DAF/COMP (2012)13/REV1 (2012); Bradūnas et al. (2010)

\section{HHI index}

Orris Herfindahl and Albert Hirshman developed an index to measure the level of competition in the early 1950s (Oliveira et al., 2016). This index is known as the HerfindahlHirschman Index (HHI) and is widely used to analyze the merger and acquisition process in a competitive business environment. In particular, the market effects on merger performance and rising prices should be assessed using an index indicating the level of concentration and market competition (Carlton, 2010; Chen et al., 2013a). In this purpose an HHI was developed to assess industrial portfolio diversification. Accordingly, market foreclosure through mergers and acquisitions is also another important issue for determining competition policy affecting market dynamics in the banking sector (Bolt and Humphrey, 2015a). Regulators often use HHI to assess competitiveness and secret behavior effect to concentration. Thus, HHI is thought to make it possible to understand competitive behavior and effective structure controversy (Bolt and Humphrey, 2015a).

For example, the Herfindahl-Hirschman Index (HHI) measures the level of concentration in the relevant geographic and product market. It is calculated on the basis of market shares squared and then summed:

$$
H H I=C_{H}=\sum_{i=1}^{k} S_{i}^{2}
$$

here:

$\mathrm{Si}$ - is the market share of the i-th company,

$\mathrm{n}$ - number of companies in the market.

The maximum value of the index is 1 , but it can be in the market with only one company, in other words, with an absolute monopoly. The minimum value of the index depends on the distribution of market shares. The low value of the index obtained indicates that the market is competitive and there are no dominant companies in it. The values of the index are assessed as follows:

$\mathrm{HHI}<0.1$ - the market is not concentrated;

$\mathrm{HHI}=0.1-0.18$ - moderately concentrated market; 
HHI $>0.18$ - the market is highly concentrated.

The main disadvantage of $\mathrm{HHI}$ is that of using existing information only the results of the current period are obtained and predictions are not available. This is because in markets that are often undergoing restructuring, it is difficult to determine the size of the market - it often changes. However, certain predictions are possible if the number of players is known and their market shares are clear.

\section{Research methodology}

It should be noted that strategic negotiating decisions in a distorted competitive market must be based on assessments of market power, otherwise they will not be of good quality and reasonable, which may affect the outcome of the negotiations. This section contains. a model for developing an construction sector's business negotiation strategy based on assessments of the bargaining power of a distorted competitive market. Making decisions in highly decisive negotiations can determine the future of a business entity. Therefore, in preparation for significant decisions, a thorough analysis of the interests and needs of the parties involved in future negotiations is needed, which would allow a better understanding of the other party's activities and priorities, and assess the available bargaining power.

It is intended to use the data of the Department of Statistics for the survey. Statistics for 2015-2019 are analyzed. Selected construction sector, specifically the following activities of the Classification of Economic Activities (NACE): 41 Construction of buildings, including 41.1 Construction development, 41.2 Construction of residential and non-residential buildings, 41.20.10 Construction of new buildings, 41.20.20 Repair, restoration and reconstruction of buildings. The company operates in the territory of Lithuania. The 18 construction companies with the highest turnover in 2019 are selected. The following performance indicators of companies in 2015-2019 are selected for analysis (Table 2):

Table 2. The limits and expressions of indices

\begin{tabular}{|c|c|c|}
\hline No. & Indicators & Units \\
\hline 1 & Turnover from construction activities (non-financial corporations) & EUR \\
\hline 2 & Gross operating profit (non-financial corporations) & EUR \\
\hline 3 & Number of hours worked by employees (non-financial corporations) & Hours \\
\hline 4 & Notional number of employees (non-financial corporations; converted into full-time equivalents) & Persons \\
\hline 5 & Total expenditure on supplies and services (non-financial corporations) & EUR \\
\hline 6 & Revenue from construction subcontracting (non-financial corporations) & EUR \\
\hline 7 & Sold tangible fixed assets (non-financial companies) & EUR \\
\hline 8 & Sales revenue & EUR \\
\hline 9 & Cost of sales & EUR \\
\hline 10 & Operating costs & EUR \\
\hline 11 & Liabilities of companies & EUR \\
\hline 12 & Equity of companies & EUR \\
\hline 13 & Corporate assets & EUR \\
\hline 14 & Debt ratio & - \\
\hline 15 & &
\end{tabular}


Further we use DEMATEL (Decision Making Trial and Evaluation) - a decision making technique based on pairwise comparisons. The DEMATEL method can be used to identify the model of causal relations between the variables (Zhang, 2020; Roy et al., 2019). It shows causal relations and the factors' exerted influences. The advantage of this method is that experts are able to be more fluent in expressing their opinions about the effects (direction and severity of effects) between factors. This method we will use analysing construction sectors economical parameters and their impact on the HHI index. The Steps of DEMATEL Method:

To identify the model of the relations among the $n$ criteria, an $n \times n$ matrix is first generated. The effect of the element in each row is exerted on the element of each column of this matrix.

$$
X=\left[\begin{array}{ccc}
0 & \cdots & x_{n 1} \\
\vdots & \ddots & \vdots \\
x_{1 n} & \cdots & 0
\end{array}\right],
$$

To normalize, the sum of all rows and columns of the matrix is calculated directly. The largest number of the row and column sums can be represented by $\mathrm{k}$. To normalize, it is necessary that each element of the direct-relation matrix is divided by $\mathrm{k}$.

$$
\begin{gathered}
k=\max \left\{\max \sum_{j=1}^{n} x_{i j}, \sum_{i=1}^{n} x_{i j}\right\}, \\
N=\frac{1}{k} * X,
\end{gathered}
$$

After calculating the normalized matrix, the fuzzy total-relation matrix can be computed as follows:

$$
T=\lim _{k \rightarrow+\infty}\left(N^{1}+N^{2}+\cdots+N^{k}\right),
$$

In other words, an $n \times n$ identity matrix is first generated, then this identity matrix is subtracted from normalized matrix and the resulting matrix is reversed. The normalized matrix is multiplied by the resulting matrix to obtain the total relation matrix.

$$
T=N \times(I-N)^{-1},
$$

The threshold value must be obtained in order to calculate the internal relations matrix. Accordingly, partial relations are neglected and the network relationship map (NRM) is plotted. Only relations whose values in matrix $\mathrm{T}$ is greater than the threshold value are depicted in the NRM. To compute the threshold value for relations, it is sufficient to calculate the average values of the matrix $\mathrm{T}$. After the threshold intensity is determined, all values in matrix $\mathrm{T}$ which are smaller than the threshold value are set to zero, that is, the causal relation mentioned above is not considered. The model of significant relations is presented in the following tables.

The next step is to find out the sum of each row and each column of T (in step 3). The sum of rows (D) and columns (R) can be calculated as follows:

$$
\begin{aligned}
& D=\sum_{j=1}^{n} T_{i j}, \\
& R=\sum_{i=1}^{n} T_{i j},
\end{aligned}
$$

Then, the values of $\mathrm{D}+\mathrm{R}$ and $\mathrm{D}-\mathrm{R}$ can be calculated by $\mathrm{D}$ and $\mathrm{R}$, where $\mathrm{D}+\mathrm{R}$ represent the degree of importance of factor $\mathrm{i}$ in the entire system and D-R represent net effects that factor $i$ contributes to the system. The table below shows the final output. This model can be represented as a diagram in which the values of $(D+R)$ are placed on the horizontal axis and the values of (D-R) on the vertical axis. The position and interaction of each factor with a point in the coordinates $(\mathrm{D}+\mathrm{R}, \mathrm{D}-\mathrm{R})$ are determined by coordinate system. 


\section{Empirical verification of the implementation of the multi-criteria evaluation model}

In this section, the model is applied and tested, which is intended to assist in the preparation construction sector's business negotiation strategies based on assessments of bargaining power. The algorithm developed on the basis of this model will be tested in a typical area of business negotiations - construction services. A typical case is characteristic for the assessment of bargaining power - the Lithuanian construction sector in 2019 real change in GDP compared to 2018 accounted for 3.9 percent, excluding seasonal and working day effects (Department of statistics, 2021). For GDP growth the greatest impact had value added growth of industrial construction and service activities. In 2019 the construction sector accounted for $8.3 \%$ of the country's GDP, or $0.5 \%$ more than in 2018 . In 2019 in the country there were 1374 thousand employed, of which 100.1 thousand or $7.3 \%$ of all employees worked in the construction sector. It has been done mainly the following works: construction, construction of industrial buildings and warehouses (Department of statistics, 2021).

After the threshold intensity is determined, all values in matrix $\mathrm{T}$ which are smaller than the threshold value are set to zero, that is, the causal relation mentioned above is not considered. In this study, the threshold value is equal to 0.048 . All the values in matrix $\mathrm{T}$ which are smaller than 0.048 are set to zero, that is, the causal relation mentioned above is not considered.

Table 3. Correlation analysis matrix

\begin{tabular}{|c|c|c|c|c|c|c|c|c|c|c|c|c|c|c|c|}
\hline & 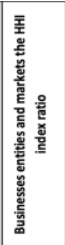 & 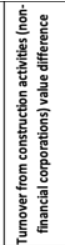 & 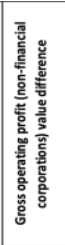 & 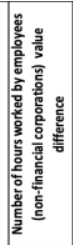 & 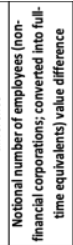 & 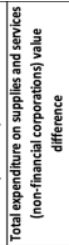 & 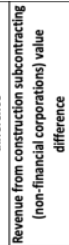 & 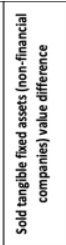 & 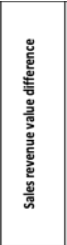 & 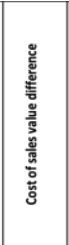 & 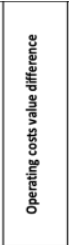 & 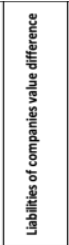 & 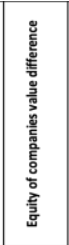 & 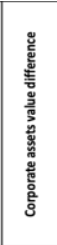 & 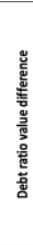 \\
\hline $\begin{array}{l}\text { Businesses entities and markets the } \mathrm{HHI} \text { index } \\
\text { ratio }\end{array}$ & 1 & 0 & 0 & 0 & 0 & 0 & 0 & 0 & 0 & 0 & 0 & 0 & 0 & 0 & 0 \\
\hline $\begin{array}{l}\text { Turnover from construction activities (non- } \\
\text { financial corporations) value difference }\end{array}$ & 0,92676 & 1 & 0 & 0 & 0 & 0 & 0 & 0 & 0 & 0 & 0 & 0 & 0 & 0 & 0 \\
\hline $\begin{array}{l}\text { Gross operating profit (non-financial } \\
\text { corporations) value difference }\end{array}$ & 0,69557 & 0,75332 & 1 & 0 & 0 & 0 & 0 & 0 & 0 & 0 & 0 & 0 & 0 & 0 & 0 \\
\hline $\begin{array}{l}\text { Total expenditure on supplies and services (non } \\
\text { financial corporations) value difference }\end{array}$ & 0,92886 & 0,99624 & 0,73027 & 0,84754 & 0,84415 & 1 & 0 & 0 & 0 & 0 & 0 & 0 & 0 & 0 & 0 \\
\hline $\begin{array}{l}\text { Revenue from construction subcontracting } \\
\text { (non-financial corporations) value difference }\end{array}$ & 0,88832 & 0,85664 & 0,5954 & 0,70364 & 0,70976 & 0,8687 & 1 & o & o & o & o & o & o & o & 0 \\
\hline $\begin{array}{l}\text { Sold tangible fixed assets (non-financial } \\
\text { companies) value difference }\end{array}$ & 0,33857 & 0,29553 & 0,35855 & \begin{tabular}{|l|l}
5 & 0,24231
\end{tabular} & 0,23722 & 0,32468 & \begin{tabular}{l|l}
3 & 0,24451
\end{tabular} & 1 & 0 & 0 & 0 & 0 & 0 & 0 & 0 \\
\hline Sales revenue value difference & 0,92607 & 0,99995 & 0,7558 & 0,86631 & 0,86312 & 0,9961 & 0,85566 & 0,29956 & 1 & 0 & 0 & 0 & 0 & 0 & 0 \\
\hline Cost of sales value difference & 0,82496 & 0,91142 & 0,63121 & 0,75369 & 0,74352 & 0,91265 & 0,72952 & 0,19963 & 0,91059 & 1 & 0 & 0 & 0 & 0 & 0 \\
\hline Corporate assets value difference & 0,64007 & 0,6143 & 0,762 & 0,49781 & 0,48794 & 0,62196 & 0,5098 & 0,52681 & 0,6172 & 0,54509 & 0,67627 & 0,9602 & 0,91584 & 1 & 0 \\
\hline Debt ratio value difference & 0,15169 & 0,30647 & 0,34545 & 0,25704 & 0,26016 & 0,30874 & 0,23522 & 0,17597 & 0,30817 & 0,27523 & 0,33552 & 0,37865 & 0,23208 & 0,3365 & 1 \\
\hline
\end{tabular}


Then, the values of $\mathrm{D}+\mathrm{R}$ and $\mathrm{D}-\mathrm{R}$ can be calculated by $\mathrm{D}$ and $\mathrm{R}$, where $\mathrm{D}+\mathrm{R}$ represent the degree of importance of factor $\mathrm{i}$ in the entire system and $\mathrm{D}-\mathrm{R}$ represent net effects that factor $\mathrm{i}$ contributes to the system. The table 4 below shows the final output.

Table 4. Final results output

\begin{tabular}{|l|l|l|l|l|}
\hline & $\mathrm{R}$ & $\mathrm{D}$ & $\mathrm{D}+\mathrm{R}$ & $\mathrm{D}-\mathrm{R}$ \\
\hline Businesses entities and markets the HHI index ratio & 1.974 & 0 & 1.974 & -1.974 \\
\hline Turnover from construction activities (non-financial corporations) value difference & 1.766 & 0.111 & 1.877 & -1.655 \\
\hline Gross operating profit (non-financial corporations) value difference & 1.312 & 0.183 & 1.495 & -1.129 \\
\hline Number of hours worked by employees (non-financial corporations) value difference & 1.181 & 0.293 & 1.474 & -0.888 \\
\hline $\begin{array}{l}\text { Notional number of employees (non-financial corporations; converted into full-time } \\
\text { equivalents) value difference }\end{array}$ & 0.942 & 0.446 & 1.388 & -0.497 \\
\hline Total expenditure on supplies and services (non-financial corporations) value difference & 0.914 & 0.623 & 1.536 & -0.291 \\
\hline Revenue from construction subcontracting (non-financial corporations) value difference & 0.604 & 0.703 & 1.307 & 0.099 \\
\hline Sold tangible fixed assets (non-financial companies) value difference & 0.405 & 0.321 & 0.726 & -0.083 \\
\hline Sales revenue value difference & 0.513 & 1.047 & 1.56 & 0.534 \\
\hline Cost of sales value difference & 0.329 & 1.132 & 1.461 & 0.804 \\
\hline Operating costs value difference & 0.306 & 0.896 & 1.202 & 0.59 \\
\hline Liabilities of companies value difference & 0.269 & 0.934 & 1.203 & 0.664 \\
\hline Equity of companies value difference & 0.141 & 1.519 & 1.661 & 1.378 \\
\hline Corporate assets value difference & 0.04 & 1.674 & 1.714 & 1.634 \\
\hline Debt ratio value difference & 0 & 0.814 & 0.814 & 0.814 \\
\hline
\end{tabular}

According to the table 4 above, each factor can be assessed based on the following aspects:

- Horizontal vector $(D+R)$ represents the degree of importance between each factor plays in the entire system. In other words, $(D+R)$ indicates both factor i's impact on the whole system and other system factors' impact on the factor. in terms of degree of importance, Businesses entities and markets the HHI index ratio is ranked in first place and Turnover from construction activities (non-financial corporations) value difference, Corporate assets value difference, Equity of companies value difference, Sales revenue value difference, Total expenditure on supplies and services (non-financial corporations) value difference, Gross operating profit (non-financial corporations) value difference, Number of hours worked by employees (non-financial corporations) value difference, Cost of sales value difference, Notional number of employees (non-financial corporations; converted into full-time equivalents) value difference, Revenue from construction subcontracting (non-financial corporations) value difference, Liabilities of companies value difference, Operating costs value difference, Debt ratio value difference and Sold tangible fixed assets (non-financial companies) value difference, are ranked in the next places.

- The vertical vector (D-R) represents the degree of a factor's influence on system. In general, the positive value of D-R represents a causal variable, and the negative value of $\mathrm{D}$ $\mathrm{R}$ represents an effect. In this study, Revenue from construction subcontracting (nonfinancial corporations) value difference, Sales revenue value difference, Cost of sales value difference, Operating costs value difference, Liabilities of companies value difference, Equity of companies value difference, Corporate assets value difference, Debt ratio value 
difference are considered to be as a causal variable, Businesses entities and markets the HHI index ratio, Turnover from construction activities (non-financial corporations) value difference, Gross operating profit (non-financial corporations) value difference, Number of hours worked by employees (non-financial corporations) value difference, Notional number of employees (non-financial corporations; converted into full-time equivalents) value difference, Total expenditure on supplies and services (non-financial corporations) value difference, Sold tangible fixed assets (non-financial companies) value difference are regarded as an effect.

This study identified which factors influence other factors and how they have a greater impact on the value of a business entity's HHI index. By knowing the key factors, they can be used to model possible mergers and their impact on the HHI index and possible changes in the market power balance. The bargaining power of the business entity can be modeled accordingly, which would act as a support for consruction sector's negotiations in preparation for business negotiations.

\section{Conclusions}

1. In this work, it is relevant in assessing the balance of bargaining power in the market. Many authors note that competition is usually measured on the basis of the following variables: market concentration, taxes, price marginal costs, and import penetration. From a structural point of view, to describe the market structure, the most important place takes the concentration measurement coefficients. These coefficients were discussed in the work and were identified which would be the best suited to assess the balance of bargaining power. Many different indices are used to measure concentration in financial markets, we distinguish the following key ones: Herfindahl-Hirschmann index (HHI), Lerner (L), $k$ firm concentration ratio (CRk), Hall-Tideman index (HTI), Rosenbluth index (RI), detailed industrial concentration index (CCI), Hannah and Kay index (HKI), U index (U), Multiplication Hause index $(\mathrm{Hm})$, Entropy measure (E). After reviewing the scientific literature and various scholars works on concentration indices, taking into account the practice of global competition authorities, we decided to analyse the balance of bargaining power in international business in the presence of a distorted market economy by using the HHI index.

2. Significant interest of researchers in the DEMATEL method is revealed in various sectors of the economy. This method also has the potential to evaluate the interaction of different criteria, which is relevant to the topic of our work. The DEMATEL method is commonly used in order to obtain a cause-and-effect scheme among the dependent factors. This method is superior to conventional methods because they are disclosed interfaces among the criteria, the criteria are ranked depending on the type of relationship and reveals the intensity of their effects for each criterion.

3. Strategic negotiating decisions in a distorted competitive market must be based on assessments of market power, otherwise they will not be of good quality and reasonable, which may affect the outcome of the negotiations. The proposed model for developing an international business negotiation strategy based on assessments of the bargaining power of a distorted competitive market. A developed algorithm for the development of an construction sector's business negotiation strategy based on evaluations of bargaining power is presented.

\section{Acknowledgements}

This project has received funding from European Social Fund (project No 09.3.3-LMT-K712-19-0025) under grant agreement with the Research Council of Lithuania (LMTLT). 


\section{References}

1. Albrecht, J., Cai, X., Gautier, P., \& Vroman, S. (2020). Multiple applications, competing mechanisms, and market power. Journal of Economic Theory, 190, 105121.

2. Bikker, J., \& Haaf, K. (2000). Measures of Competition and Concentration in the Banking Industry: a Review of the Literature. Economic and Financial Modelling. 9.

3. Bikker, J.A., Haaf, K. (2002). Competition, concentration and their relationship: an empirical analysis of the banking industry. Journal of Banking and Finance, 26(11), 2191-2214.

4. Blundell, R., Griffith, R., \& Reenen, V. J. (1999). Market Share, Market Value and Innovation in a Panel of British Manufacturing Firms. Review of Economic Studies, 66(3), 529-554.

5. Bolt, W., \& Humphrey, D. (2015a). Assessing bank competition for consumer loans. Journal of Banking and Finance, 61, 127-141.

6. Bradūnas, V., Mikelionytè, D., \& Petrauskaite, L. (2010). Lietuvos duonos rinkos koncentracijos poveikio kainoms ekonominis vertinimas: Mokslo studija. Vilnius: Lietuvos agrarinès ekonomikos institutas [ţiūrèta $2011 \mathrm{~m}$. spalio 14 d.]. Retrieved from: http://www.laei.lt/?mt=leidiniai\&straipsnis=329\&metai=2010.

7. Carlton, D.W. (2010). Revising the horizontal merger guidelines. Journal of Competition Law and Economics, Vol. 6 No. 3, pp. 619-652.

8. Chen, Y., Wei, X., \& Zhang, L. (2013a). A new measurement of sectoral concentration of credit portfolios. Procedia Computer Science, 17, 1231-1240.

9. DAF/COMP(2012)13/REV1. (2012). Market definition. Directorate For Financial And Enterprise Affairs Competition Committee, 85.

10. Department of Statistics (2021). Lithuania's construction sectors business entities activity data 2015-2019. Retrieved from : https://www.stat.gov.lt/

11. Gancevskaite, K. (2008). Research of competition in Lithuanian life insurance market. Master thesis. Vytauto Didžiojo universitetas, 87. Retrieved from: https://hdl.handle.net/20.500.12259/124545

12. Yeh, Y. H, \& Liao, C. C. (2020). The impact of product market competition and internal corporate governance on family succession. Pacific-Basin Finance Journal, 62, 101346.

13. Yung, K., \& Nguyen, T. (2020). Managerial ability, product market competition, and firm behavior. International Review of Economics \& Finance, 70, 102-116.

14. Kadoić, N., Ređep, N., B., \& Divjak, B. (2017). Decision making with the analytic network process. Computer Science. 1-7.

15. Lee, C. F., \& Sung, H. C. (2021). Product market competition and real activities manipulation: Theory and implications. International Review of Economics \& Finance, 74, 192-205.

16. Li, S., Liu, Q., \& Refalo, J. (2020). Industry classification, product market competition, and firm characteristics. Finance Research Letters, 36, 101319.

17. Marshall, L., Bruce, A., \& MacGill, I. (2021). Assessing wholesale competition in the Australian National Electricity Market. Energy Policy, 149, 112066.

18. Moul, C. C., \& Miller, B. A. (2021). An aggregate test for transient market power in the winter 2013-14 propane market, Economics Letters, 200, 109765.

19. Nickell, S. (1996). Competition and Corporate Performance. Journal of Political Economy, 104, 724-746. 
20. Oliveira, A.V., Lohmann, G., \& Costa, T.G. (2016). Network concentration and airport congestion in a post de-regulation context: case study of Brazil 2000-2010. Journal of Transport Geography, 50, 33-44.

21. Prayoonrattana, J., Laosuthi, T., \& Chaivichayachat, B. (2020). Empirical Measurement of Competition in the Thai Banking Industry. Economies, 8(2), 44.

22. Rahman, D., Kabir, M., \& Oliver, B. (2021). Does exposure to product market competition influence insider trading profitability? Journal of Corporate Finance, 66, 101792.

23. Roy, J., Sharma, H. K., Kar, S., Zavadskas, E. K., \& Saparauskas, J. (2019). An extended COPRAS model for multi-criteria decision-making problems and its application in webbased hotel evaluation and selection. Economic Research-Ekonomska Istraživanja, 32(1), 219-253.

24. Zhang, R. (2020). Trade credit, cash holdings, and product market competition. The Quarterly Review of Economics and Finance. 78, 132-146. 